\title{
РАЗВИТИЕ МОДЕЛИ РАЙОНА УЗОН-ГЕЙЗЕРНОЙ ВУЛКАНО-ТЕКТОНИЧЕСКОЙ ДЕПРЕССИИ И ВУЛКАНА КИХПИНЫЧ (КАМЧАТКА) ПО РЕЗУЛЬТАТАМ СОВМЕСТНОГО АНАЛИЗА ДАННЫХ МИКРОСЕЙСМИЧЕСКОГО ЗОНДИРОВАНИЯ И ЛОКАЛЬНОЙ ГЕОДИНАМИЧЕСКОЙ АКТИВНОСТИ
}

\author{
(C) 2015 г. . Н. Кугаенко ${ }^{1}$, В. А. Салтыков ${ }^{1}$, А. В. Горбатиков ${ }^{2}$, М. Ю. Степанова \\ ${ }^{1}$ Камчатский филиал Геофизической службы РАН, г. Петропавловск-Камчатский \\ E-mail: ku@emsd.ru \\ ${ }^{2}$ Институт физики Земли им. О.Ю. Шмидта РАН, г. Москва \\ E-mail:avgor70@mail.ru \\ Поступила в редакцию 05.09.2014 г.
}

\begin{abstract}
По данным микросейсмического зондирования построена глубинная модель среды под районом УзонГейзерной вулкано-тектонической депрессии и прилежащего к ней вулканического массива Кихпиныч (Камчатка) до глубины 30 км. Для этого была осуществлена регистрация естественного фонового микросейсмического поля переносными широкополосными сейсмометрами Guralp CMG-6TD в точках специально спланированной наблюдательной сети: в 60-ти точках вдоль трех профилей общей длиной около 28 км. Выявленные структурные неоднородности проинтерпретированы с учетом известных ранее результатов геологических, геолого-морфологических и петрологических исследований. Идентифицирована и пространственно локализована область малоглубинного закристаллизовавшегося магматического очага под депрессией. Выявлены области предположительной концентрации базальтовых расплавов, с которыми может быть связана наблюдающаяся в последние 15 лет локальная геодинамическая активизация исследуемого района: периферический магматический очаг вулканического массива Кихпиныч на глубине 5-12 км и более глубокая (15-20 км) магматическая камера. Получено согласие геометрии обнаруженных глубинных структур с локальной микросейсмичностью и моделью современного магматического внедрения в верхние горизонты коры, разработанной по данным спутниковой интерферометрии.
\end{abstract}

DOI: $10.7868 / \mathrm{S} 0002333715030096$

\section{ВВЕДЕНИЕ}

Узон-Гейзерная вулкано-тектоническая депрессия и вулканический массив Кихпиныч являются частью Восточно-Камчатского вулканического пояса и относится к территории Кроноцкого государственного природного биосферного заповедника (восточное побережье полуострова Камчатка, рис. 1). Депрессия включает в себя два всемирно известных природных объекта: Долину Гейзеров и кальдеру Узон, входящих в списки объектов всемирного природного наследия ЮНЕСКО.

Вулкано-тектонические депрессии и кальдеры постоянно привлекают внимание исследователей: обычно они являются поверхностным выражением обширных, но неглубоких магматических очагов, с ними связывается гидротермальная деятельность и рудообразование.

В 1970-1990-х годах в районе Узон-Гейзерной вулкано-тектонической депрессии был выполнен большой объем геологических, петрологических и гидрогеологических работ [Вулканизм..., 1974; Белоусов, 1978; Белоусов и др., 1983; Брайцева и др., 1991; Леонов, 1989; 2001; Леонов, Гриб, 1998; 2004; Леонов и др., 1991]. В 2012 г. в западной части депрессии (в пределах кальдеры Узон) было проведено электромагнитное профилирование, позволившее разработать локальную глубинную гидрогеологическую модель до глубины около 5 км [Мороз и др., 2013]. Сейсмологические исследования района депрессии и прилежащих к ней территорий до последнего времени не проводились, а постоянные GPS-пункты и региональные сейсмостанции отсутствуют. Поэтому геофизическую изученность района можно считать слабой, в особенности это касается вулкана Кипиныч и восточной части депрессии и их глубинного строения.

В условиях отсутствия какого-либо инструментального мониторинга исследуемой территории важным (и неожиданным) фактом, свидетельствующим о продолжающейся геодинамической активности этого района, может служить зафиксированное средствами спутниковой интероферометрии поднятие восточной части депрессии и примыкающего к ней вулканического массива Кихпиныч 
[Lundgren, Lu, 2006; Pritchard, Simons, 2004]. Также неожиданной является активизация процессов склоновой неустойчивости долины реки Гейзерной, обернувшихся геологическими катастрофами для Долины Гейзеров и уничтоживших часть гейзеров и других природных достопримечательностей: гигантский оползень 03.06.2007 г. (объем отложений около $21 \times 10^{6} \mathrm{M}^{3}$ ) [Пинегина и др., 2008; Двигало, Мелекесцев, 2009] и крупный обвал борта депрессии 3-4.01.2014 [Леонов, 2014].

Отчетливо обозначились проблемы ограниченности наших знаний об опасных эндогенных и экзогенных процессах этой уникальной территории, связанные с отсутствием систем мониторинга и недостаточными представлениями о глубинном строении магматической системы.

Появление в арсенале геофизических методов новой эффективной технологии для оценки параметров геологических объектов - методики микросейсмического зондирования [Горбатиков и др., 2008; Горбатиков, Цуканов, 2011] - позволило в определенной мере развить модель глубинной структуры района Узон-Гейзерной депрессии, уточнить имеющиеся представления о магматическом очаге и выявить новые особенности строения земной коры. С этой целью в районе депрессии в соответствии с требованиями технологии микросейсмического зондирования была осуществлена регистрация естественного фонового микросейсмического поля переносными широкополосными сейсмометрами Guralp $C M G-6 T D$ в точках специально спланированной наблюдательной сети.

Описание особенностей технологического подхода, представление проведенных исследований, а также интерпретация полученных результатов составляют содержание данной статьи. Также для развития представлений о глубинном строении магматической системы мы постарались обобщить все имеющиеся независимые сведения о районе исследований, в том числе факты о его геодинамической активизации, и сопоставить их с новыми сейсмологическими данными - результатами выполненного нами микросейсмического зондирования.

\section{ХАРАКТЕРИСТИКА РАЙОНА ИССЛЕДОВАНИЙ}

Термин “вулкано-тектоническая депрессия" обычно применяется для обширных просадок, включающих в себя вулканические постройки и часто группы кальдер, с которыми практически во всех случаях связаны извержения кислой пирокластики. Этот термин традиционно относится и к Узон-Гейзерной структуре.

Узон-Гейзерная вулкано-тектоническая депрессия представляет собой вулканическую структуру овальных очертаний, вытянутую в широтном направлении и имеющую размеры по кромке ограни- чивающих ее уступов $\sim 9 \times 18$ км (рис. 1 , рис. 2 ). В тектоническом отношении она приурочена к крупному прогибу мел-палеогенового фундамента (Восточно-Камчатскому, или Тюшевскому), заполненному преимущественно неогеновыми вулканогенно-осадочными отложениями. История геологических исследований депрессии наиболее полно отражена в библиографиях к работам [Леонов, 1989; Леонов, Гриб, 2004].

Вулкан Кихпиныч нельзя отнести к числу хорошо исследованных объектов. История эруптивной деятельности Кихпиныча и представления о его возможной активности в будущем представлены в статьях [Брайцев и др., 1985; 1991; Брайцев, Пономарев, 1991]. О сейсмичности этого вулкана в настоящее время известны лишь сведения, приведенные ниже в нашей статье, ранее локальные наблюдения здесь не проводились.

Ранее предполагалось, что в образовании Узон-Гейзерной вулкано- тектонической депрессии большую роль играли тектонические процессы [Вулканизм..., 1974]. Однако детальные исследования по изучению бортов выявили, что для выделения крупных разломов, формирующих границы этой структуры, нет оснований. УзонГейзерная депрессия состоит не менее чем из 6 отдельных разновозрастных кальдер [Леонов, Гриб, 1998; 2004], образовавшихся от 280 до 40 тыс. лет назад [Bindeman et al., 2010], но их выделение и описание затруднены из-за того, что вся внутренняя часть впадины заполнена мощной толщей озерных отложений и экструзивными куполами. Границы депрессии образованы фрагментами этих слившихся кальдер. В данном случае по отношению к УзонГейзерной структуре правильнее было бы применять термин "кальдерная система".

Западная часть Узон-Гейзерной кальдерной системы представляет собой впадину с относительно плоским дном, где расположены многочисленные озера, грязевые котлы и термальные источники. Она носит собственное название - кальдера Узон. Вдоль восточной границы депрессии пролегает глубокий каньон с разнообразными термальными источниками, в том числе гейзерами, Долина Гейзеров. Эту часть депрессии относят к Гейзерной кальдере, наиболее древней части кальдерной системы, возраст которой по последним данным оценивается в 280 тыс. лет [Bindeman et al., 2010].

Над восточным бортом Узон-Гейзерной депрессии возвышается сложный средне-верхнеплейстоценовый вулканический массив Кихпиныч, который состоит из нескольких слившихся разновозрастных вулканических сооружений [Брайцева и др., 1991]. Его основание - вулкан Старый Кихпиныч сформировался до этапа кальдерообразования в Восточном вулканическом поясе (средний-верхний плейстоцен). Кихпиныч относится к актив- 
ным вулканам на основании современной слабой фумарольной деятельности и достаточно свежим лавовым потокам. Наиболее молодой конус Савича образовался около 1400 лет назад и остается активным до настоящего времени. Последняя активизация вулкана произошла менее 600 лет назад.

Прогноз будущей эруптивной деятельности неоднозначен [Брайцева и др., 1985; Брайцева, Пономарева, 1991]. По одному из сценариев, описанных в указанных работах, конус Савича находится в состоянии покоя, завершающем длительный цикл его активности. Исходя из истории развития вулкана Кихпиныч, текущий период покоя может длиться еще более 2 тыс. лет, после чего последует либо разрушение вершины взрывом, либо смещение эруптивного канала и построение нового конуса вулкана. По второму возможному сценарию в настоящее время наблюдается лишь перерыв в нормальной деятельности конуса Савича и уже в ближайшее время не исключается мощное эксплозивно-эффузивное извержение, поскольку состояние покоя длится уже довольно долго - несколько сотен лет.

В работе [Белоусов, 1978] в качестве активной самостоятельной структуры выделен Кихпинычский долгоживущий вулканический центр (ДВЦ) (рис. 2), который включает массив Кихпиныч и восточную часть Узон-Гейзерной депрессии (Долину Гейзеров и Гейзерную гидротермальную систему). К особенностям ДВЦ можно отнести отсутствие постоянного фиксированного канала извержения, возможную миграцию центров извержений и пульсирующий характер переноса материала и тепла в ходе вулканического процесса.

По последним данным инфракрасной съемки в наиболее молодой части Кихпинычского ДВЦ выявлены изменения в температурном режиме и новые, ранее не отмечавшиеся термальные аномалии [Карданова, Дубровская, 2012], что, возможно, связано с активизацией геодинамических процессов под вулканическим центом.

Исследуемый район связан с узлом пересечения крупных региональных разломов: магмо- и флюидопроводящего Вулканического раздвига северо-восточного простирания и субширотного Узон-Валагинского глубинного сдвига, рис. 1 [Белоусов и др., 1983; Леонов, 1989]. С этими региональными структурами связаны две системы поверхностных разрывных нарушений соответствующих простираний. Также выделяется сеть разломов, ориентированных по отношению к Узон-Гейзерной депрессии концентрически. В четвертичное время Узон-Валагинский разлом выступает как структура растяжения, представленная на поверхности серией сбросов и трещин и трассируемая цепочкой вулканических построек.

Известно, что на месте Узон-Гейзерной депрессии существовала группа вулканов с состава- ми лав и пирокластики от базальтов до риолитодацитов. К югу и северу от зоны разломов субширотного простирания располагались вулканические центры различного состава: базальтовые вулканы к северу и вулканические аппараты, поставляющие кислую магму, - к югу [Вулканизм..., 1974; Леонов, Гриб, 2004].

Известно также, что имеются отличия в составе пород для различных этапов активности УзонГейзерной структуры. На докальдерном этапе состав преимущественно базальтоидный, на кальдерообразующем - дацитовый. Посткальдерный этап характеризуется бимодальным вулканизмом из-за широкого развития в этом районе пород основного (базальтоидного) и кислого (дацит-риолитового) состава [Леонов, Гриб, 2004], (рис. 2б). В пределах Узон-Гейзерной депрессии на поскальдерном этапе базальты изливались в основном у границ депрессии и за ее пределами, что может указывать на существование верхнекорового очага, который выполнял экранирующую роль для нижнекоровых расплавов [Леонов, Гриб, 2004]. Породы вулкана Кихпиныч представлены базальтами и андезибазальтами.

Магматический очаг под Узон-Гейзерной структурой детально изучен геологическими и петрологическими методами. Предполагается, что коровый очаг кислой магмы существовал здесь по крайней мере с нижнечетвертичного времени и имел температуру, близкую к солидусу [Леонов, 1989; Леонов, Гриб, 2004]. Из-за особенностей геологического строения района его история восстановлена только со среднечетвертичного времени. Установлено три периода активизации деятельности корового очага в результате инъекций высокотемпературных глубинных базальтов. Снижение объема продуктов кислого вулканизма от цикла к циклу и увеличение степени кристалличности лав вызваны постепенной закристаллизацией очага в течение верхнего плейстоцена. По петрологическим данным сделан вывод о неравновесных условиях кристаллизации расплава и большой скорости его остывания; считается, что к настоящему моменту очаг в значительной степени закристаллизовался [Леонов, 1989; Леонов, Гриб, 1998; 2004].

Для восточной части Узон-Гейзерной депрессии глубина верхней кромки коровой магматической камеры была рассчитана по структурным данным (по системе даек, связанных с дуговыми разломами, ограничивающими кальдеру) и составила для среднего-верхнего плейстоцена 7-8 км [Белоусов и др., 1983].

В настоящее время геодезический мониторинг на исследуемой территории не осуществляется. Наши знания о движениях земной коры в этом районе ограничены опубликованной информацией о том, что в 2000-2003 гг. по данным спутника RADARSAT-1 на базе интерферометрических 
методов (InSAR) было зафиксировано поднятие восточной части депрессии и примыкающего к ней вулканического массива Кихпиныч [Lundgren, Lu, 2006] (рис. 2в). Важно, что поднятие не сопровождалось активизацией сейсмичности на уровне чувствительности Камчатской региональной сети сейсмических станций. Это не совсем обычно, хотя в практике вулканологических исследований имеются примеры асейсмичного развития аналогичных деформационных процессов в областях современного вулканизма [Dzurisin et al., 2009; Lu et al., 2000; 2002].

В работе [Lundgren, Lu, 2006] исследована возможная конфигурация глубинного внедрения, вызвавшего зафиксированную деформацию дневной поверхности. По результатам проведенного моделирования наиболее возможным источником деформации является наклонный силл неправильной формы в диапазоне глубин 4-8 км под восточной частью Узон-Гейзерной депрессии, линейные размеры которого ориентировочно составляют $9 \times 15$ км. Ниже мы сопоставим эту модель в с новыми результатами.

Основное количество землетрясений Камчатки сосредоточено в сейсмофокальной зоне, наклонно уходящей под полуостров. Под исследуемой территорией сейсмофокальная зона находится на глубине 120-140 км. При существующей конфигурации Камчатской региональной сейсмологической сети уровень надежной регистрации здесь оценивается в $K_{S}=7.5\left(K_{S}-\right.$ энергетический класс по [Федотов, 1972]). В этом районе фиксируются редкие единичные мелкофокусные землетрясения низкого энергетического уровня $K_{S}=7-9$.

За последнее столетие исследуемый район 3 раза испытывал сотрясения с интенсивностью 7-8 баллов (в 1923, 1927, 1959 гг.) и 4 раза с интенсивностью 6 баллов (в 1952, 1971, 1997 и 2013 гг.) по шкале MSK-64. Эти сотрясения были вызваны сильнейшими за годы инструментальных наблюдений региональными землетрясениями, которые произошли вдоль восточного побережья Камчатки и имели магнитуды $M=7.5-9.0$, а также глубокофокусным Охотоморским землетрясением 24.05.2013 Mw = 8.3, вызвавшим аномальный по дальности макросейсмический эффект [Чебров и др., 2013].

В ходе первых временны́х сейсмологических полевых наблюдений 2008-2009 гг., которые были организованы в восточной части Узон-Гейзерной депрессии после катастрофического оползня 2007 г., зарегистрировано большое число слабых локальных землетрясений $K_{S}=3-7$ [Кугаенко и др., 2010]. Эпицентры землетрясений расположены компактно и в основном попадают под Кихпинычский ДВЦ (рис. 3). Глубина землетрясений не превышает 5 км. Наиболее глубокие из зарегистрированных событий располагаются под зоной экструзий в восточной части депрессии (под Гейзерной кальдерой). Большая часть сейсмических событий связана с областью гидротермальных проявлений западной части вулканического массива Кихпиныч.

Выделяются две группы событий (рис. 3): первая - под Гейзерной кальдерой и Долиной Гейзеров (гр. $\boldsymbol{I})$, вторая тяготеет к вулкану Кихпиныч (гp. K).

События гр. $\boldsymbol{\Gamma}$ немногочисленны. Они попадают в диапазон глубин 1-5 км, погружая от Долины Гейзеров на запад, под зону экструзивных куполов в восточной части депрессии. Наклонная плоскость, очерченная гипоцентрами гр. $\boldsymbol{\Gamma}$, выходит на дневную поверхность в районе бортового уступа кальдеры, в зоне произошедших в 2007 и 2014 гг. обрушений склонов.

$\boldsymbol{F p} . \boldsymbol{K}$ захватывает диапазон глубин до 2 км. Находившейся в этой зоне временно́й сейсмической станцией зафиксировано более 100 слабых землетрясений с $T s-p<1$ c. Сейсмичность этой зоны неравномерно распределена во времени и носит роевой характер. Следует отметить, что землетрясения гp. $\boldsymbol{K}$ происходят в области современных гидротермальных проявлений, однако по характеру записей относятся к тектоническим, с четкими вступлениями объемных волн.

Пространственное распределение гипоцентров локальных землетрясений хорошо согласуется с моделью глубинного источника поверхностной деформации, предложенной в [Lundgren, Lu, 2006] по данным $S A R$-интерферометрии. Локальные землетрясения сосредоточены в двух пространственно разобщенных группах событий, совпадающих с областями максимальных модельных глубинных подвижек, вызвавших поверхностную деформацию (рис. 1, рис. 5). Это позволяет рассматривать сейсмические события, зарегистрированные временно́й сетью в 2008-2009 гг., как одно из проявлений активности Кихпинычского ДВЦ.

Локальные сейсмологические исследования в районе Долины Гейзеров носили кратковременный эпизодический характер и не отражают в полной мере современное состояние сейсмичности этого района и вулкана Кихпиныч.

\section{МЕТОД ИССЛЕДОВАНИЯ}

Как уже упоминалось, в данном исследовании для оценки модели глубинной структуры использовался метод микросейсмического зондирования (ММЗ). ММЗ относится к группе пассивных методов сейсморазведки и может применяться при решении геолого-геофизических и структурных задач для различных классов геологических объектов в различных географических и климатических условиях [Горбатиков и др., 2008; Горбатиков, Цуканов, 2011]. К настоящему времени накоплен значительный опыт использования ММЗ 
в научно-исследовательских и промышленных проектах на территории России, стран СНГ и за рубежом [Gorbatikov et al., 2013; Горбатиков и др., 2008; 2009; 2010; 2011; 2015; Рогожин и др., 2009; Кугаенко и др., 2013].

Распространенными в мире методами, родственными ММ3, являются: 1) модификации метода поверхностно-волновой томографии на основе оценки по кросс-корреляционной функции фазовой части функции Грина; 2) модификации метода пространственной корреляции (SPAC- методы); 3) модификации метода отношения компонент $(H / V$ методы) коры [Королева и др., 2009; Gerstoft et al., 2006; Lin et al., 2008; Sabra et al., 2005; Shapiro, Campillo, 2004; Shapiro et al., 2005; Stehly, 2009; Yang, Ritzwoller, 2008; и др.]. При всем разнообразии технологий реализации (а именно, применение сейсмических групп или отдельных точечных измерений) перечисленные подходы объединены тем, что используемая в них модель формирования микросейсмического поля базируется на представлении об обязательной выдержанной локальной слоистости среды. Соответственно, горизонтальное разрешение этих методов составляет величину $3-5 \lambda$ ( $\lambda-$ длина волны фундаментальной моды Рэлея, взаимодействующая с неоднородностью).

Модель формирования микросейсмического поля в ММЗ не исходит из обязательной выдержанной по горизонтали слоистости среды. В этой связи считается, что основной вклад в микросейсмическое поле вносится фундаментальными модами Рэлея, а наличие высших мод минимально. Информативным параметром (полезным сигналом) в ММЗ является степень искажения амплитудного поля при взаимодействии со скоростными неоднородностями. Фазовая информация не используется. Форма и глубина залегания неоднородности оценивается исходя из распределения искажений исходного поля на поверхности и частоте, на которой эти искажения проявляются. В работе [Горбатиков, Цуканов, 2011] показано, что на поверхности Земли над высокоскоростными неоднородностями (скорости упругих волн в неоднородности выше, чем во вмещающей среде) спектральные амплитуды в определенном частотном диапазоне уменьшаются, а над низкоскоростными (скорости ниже, чем во вмещающей) - возрастают. Существует критическая частота $f$ волны Рэлея, для которой искажения от неоднородности, залегающей на глубине $H$ максимальны по сравнению с искажениями от этой же неоднородности на соседних частотах спектра. Эта частота $f$ связана с глубиной $H$ и соответствующей скоростью фундаментальной моды волны Рэлея $V_{R}(f)$ через соотношение: $H \approx 0.4 V_{R}(f) / f=0.4_{R}(f)$. Это подтверждается модельными расчетами и исследованиями геологических объектов различного масштаба и генезиса. Данное соотношение используется в ММЗ для оценки глубины залегания неизвестной неоднородности, формирующей амплитудные искажения (которые мы можем наблюдать) на частоте $f$. Данная оценка глубины производится из предположения, что в микросейсмическом поле $f$ однозначно связана с $\lambda_{R}(f)$ - длиной волны фундаментальной моды Рэлея. При этом не предполагается наличия выдержаных по горизонтали слисто-горизонтальных сред с высоким контрастом скоростей между слоями. В этой связи считается, что высшие моды Рэлея всегда имеют амплитуды меньшие, чем фундаментальная мода.

Согласно численным экспериментам [Горбатиков, Цуканов, 2011], разрешающая способность метода при восстановлении изображения по горизонтали оценивается как $(0.25-0.3) \lambda$, где $\lambda-$ эффективная зондирующая длина волны. Оценка разрешения по вертикали составляет величину (0.3-0.5) $\lambda$, где $\lambda-$ эффективная длина волны для средней глубины между неоднородностями. Также показано, что обнаружить присутствие изолированной малой неоднородности возможно, даже если ее размеры меньше длины волны в 10 и более раз.

Методика проведения полевых измерений сводится к накоплению спектра мощности микросейсмического сигнала в течение некоторого времени последовательно от точки к точке вдоль профиля одним или несколькими переносными датчиками. Одновременно регистрируется микросейсмический сигнал на опорной точке в пределах исследуемого полигона. Коррекция на нее выполняется для устранения эффекта нестационарности зондирующего микросейсмического сигнала. В зависимости от поставленной задачи возможно проведение как профильной, так и площадной съемки.

Таким образом, ММЗ позволяет построить разрез локальных скоростных пространственных вариаций по отношению к некоторой средней региональной скоростной модели, которая либо берется из независимых источников, либо строится независимо от ММЗ с помощью активных или пассивных (в том числе перечисленных выше) сейсмологических методов.

Разрезы строятся в тонах цвета, интенсивность заливки которого соответствует степени отклонения скоростей сейсмических волн от сглаженной региональной скоростной модели. Считается, что скорости $V_{p}$ и $V_{S}$ для всех глубин изменяются согласовано, и $V_{p}=\sqrt{3} V_{s}$. Степень отклонения от сглаженной модели выражается в децибелах и определяется согласно тоновой шкале.

Вспомним, что дисперсионная кривая, рассчитанная по горизонтально слоистой скоростной модели, ведет себя достаточно устойчиво по отношению даже к значительным вариациям скоростей в слоях исходной модели. С этим, кстати, связана неединственность решения обратной за- 
дачи строения на основе измерения дисперсионной картины, известная многим исследователям. Поскольку в методе ММЗ предполагается наличие однозначной связи между длиной волны и глубиной [Горбатиков, Цуканов, 2011] , то для каждого исследуемого региона предлагается формально заменить региональную горизонтально-слоистую скоростную модель, на гладкую модель, оцененную из дисперсионной кривой $V_{R}(f)$ с использованием того же соотношения, что принято в ММЗ, а именно $H \approx$ $\approx 0.4 V_{R}(f) / f$.

Для того, чтобы оценить насколько такая замена исказит окончательный разрез, получаемый по MМ3, нужно на основе замененной региональной модели заново рассчитать дисперсионную кривую и сравнить дисперсионные кривые по первоначальной региональной модели и по гладкой региональной модели. Конкретный анализ показал, например, что скорости по дисперсионной кривой по модели горной части Кавказа и дисперсионной кривой по сглаженной модели не различаются более, чем на 4\% для всех частот [Горбатиков и др., 2015]. При этом отличие исходной горизонтально - слоистой скоростной модели от гладкой модели на отдельных глубинах может достигать 7-8\%. Для расчета дисперсионной кривой по региональной модели можно использовать программу расчета поверхностной фундаментальной моды Рэлея методом Томпсона-Хаскела для горизонтально-слоистой модели среды.

Прямая задача формирования полезного сигнала в ММЗ для случаев одиночных тел простой формы подробно рассмотрена в работе [Горбатиков, Цуканов, 2011], где на разработанном комплексе программ проведены расчеты влияния заглубленных включений на пространственное распределение спектра мощности поля поверхностных волн Рэлея. Рассмотрены включения различной формы, размеров, глубины залегания и скоростного контраста по отношению к вмещающей среде, но при этом рассмотрение ограничено случаями с неизменным значением коэффициента Пуассона в неоднородности и вмещающей среде. Показано, что амплитудная реакция не чувствительна к форме скоростного включения, если его размеры не превышают $\lambda / 4$, где $\lambda$ - длина фундаментальной моды волны Рэлея, соответствующая глубине залегания. При этом возможно обнаружить присутствие самого включения и определить знак его скоростного контраста. В терминах глубин, используя коэффициент глубинной привязки, можно утверждать, что изображения двух неоднородностей со скоростными контрастами одного знака должны сливаться, если расстояние между ними составляет половину глубины их залегания или менее.

Основные закономерности формирования сигнала в ММЗ, полученные на численной модели, находятся в хорошем соответствии с результатами полевых экспериментов. Тем не менее, в ря- де экспериментальных наблюдений было обнаружено, что полученные изображения не соответствуют результатам описанной серии численных расчетов. В частности это относится к возможности раздельного наблюдения двух субвертикальных структур на глубинах, где, в соответствии с расчетами, изображения должны сливаться в одно, то есть, наблюдается “сверхразрешение”. Это обнаруженное несоответствие между результатами расчетов и экспериментов потребовало проведения дополнительного исследования, в ходе которого было показано, что эффект “сверхразрешения” может наблюдаться, если коэффициент Пуассона материала включения приближается к нулевому значению [Gorbatikov et al., 2013]. В природных условиях это может означать наличие развитой микротрещинноватости.

К настоящему времени на численных моделях изучены вопросы: 1) о влиянии коэффициента Пуассона неоднородности на ее изображение в микросейсмическом поле; 2) об оценке величины нелинейного эффекта амплитудной реакции в ММЗ в случае двух близкорасположенных заглубленных тел.

Решение обратной задачи в методе микросейсмического зондирования так же как и в большинстве геофизических методов не единственно. Невозможно восстановить сложный комплекс параметров среды, исходя только из распределения амплитудной реакции неоднородностей на облучение микросейсмическими волнами. Тем не менее, сам характер проявления геологических объектов в разрезах ММЗ может нам дать информацию, полезную для геологической и тектонической интерпретации.

Обратим внимание, что субвертикальные геологические неоднородности и скоростные границы для ММЗ являются предпочтительными, а субгоризонтальные границы - "неудобными" объектами. При этом вспомним, что для сейсморазведки МОВ субгоризонтальные геологические тела и скоростные границы являются предпочтительными объектами. Это объясняется взаимным пространственным положением волновых фронтов и скоростных границ. Так, идеальная горизонтальная в пределах измерительного профиля скоростная граница в ММЗ будет незаметна. О горизонтальных границах в ММЗ можно судить по нарушению характера волновой картины, по аналогии с тем, как определяют присутствие и положение субвертикальных разломов в МОВ. В этом смысле ММЗ можно рассматривать как своеобразное “ортогональное дополнение” к МOB.

\section{СИСТЕМА НАБЛЮДЕНИЙ И АППАРАТУРА}

В 2009 г. в ходе полевых работ в районе Кихпинычского ДВЦ (район “Восточная часть УзонГейзерной депрессии - вулкан Кихпиныч”) была 
выполнена съемка микросейсмического поля на взаимно перпендикулярных профилях (рис. 2a).

Для регистрации использовались портативные широкополосные цифровые велосиметры Guralp $C M G-6 T D$, сочетающие в себе функции сейсмического датчика и цифрового регистратора. Частотный диапазон от 0.03 до 50 Гц; чувствительность 2 $\times 1200$ В/м/с; частота оцифровки 100 отсч./сек. Для точной временно́й привязки информации используется выносной $G P S$-приемник, связанный с CMG-6TD через коммутационный блок. Управление сейсмометром осуществлялось с помощью портативного компьютера. Электропитание обеспечивалось аккумулятором $U=12 \mathrm{~V}$.

Профили были заложены с учетом имеющихся данных о геологическом строении района, сложного рельефа и результатов спутниковой интерферометрии.

Профиль $\boldsymbol{I}$ пересек восточную часть и борт Узон-Гейзерной депрессии в направлении ЮВ C3, вкрест Долины Гейзеров. Профиль II субмеридионального простирания прошел вдоль восточного борта депрессии и захватил западное подножье вулканического массива Кихпиныч. Для возможности оценки достоверности получаемых экспериментальных разрезов был пройден профиль II-a, смещенный относительно профиля II на 500 м к востоку. Профилирование производилось в виде пошаговой регистрации микросейсмического поля с расстоянием между точками 500 м. Длина профиля $\boldsymbol{I}$ составила 10 км, профиля $\boldsymbol{I I}-11 \mathrm{KM}$, профиля $\boldsymbol{I I}-\boldsymbol{a}-7 \mathrm{KM}$.

Регистрация в каждой точке профиля длилась не менее 2 часов, что определялось временем, необходимым для достижения статистической устойчивости спектра. $C M G-6 T D$ обеспечивают надежную регистрацию поверхностных волн длиной до 100 км (при скоростях волн Рэлея до 4 км/сек) и глубину зондирования до 40 км. Для компенсации временнь́іх вариаций в спектре зондирующего микросейсмического сигнала одновременно с измерениями вдоль профилей была проведена регистрация микросейсмического поля опорной станцией.

\section{РЕЗУЛЬТАТЫ И ОБСУЖДЕНИЕ}

На рис. 4 представлены вертикальные разрезы, построенные по результатам измерений, отражающие распределение относительных скоростей поперечных сейсмических волн. Видно, что раз-

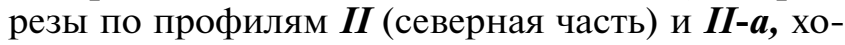
рошо согласуются между собой, что подтверждает существование выявленных неоднородностей и свидетельствует о достоверности полученных результатов.

Как ясно из описания, метод микросейсмического зондирования является относительным, и поэтому корректная интерпретация полученных результатов связана, в первую очередь, с согласованностью разрезов и известных поверхностных геологических условий на площади исследования. Для проведения этого сравнения профили были разбиты на участки и пронумерованы в соответствии с их геологическими характеристиками (рис. 4), которые приводятся в таблице "Геологические характеристики участков профилей, выделенных на рис. 4”.

Профиль I проходит вкрест Долины Гейзеров и восточного борта депрессии. Распределение относительных скоростей до глубин $\sim 1$ км хорошо коррелирует с основными чертами сложного контрастного геологического разреза восточной части структуры. Например, отчетливо различается субвертикальная граница между участками А7 и А6, совпадающая в пространстве с восточным бортом депрессии (см. таблицу). Сопоставляя рис. 4 и таблицу, можно заметить хорошее соответствие между разрезами и известными геологическими особенностями также на других участках.

В частности, относительно высокоскоростная зона 1 (профиль I) ввиду ее приуроченности к г. Белая, может быть интерпретирована, как затвердевший лавовый массив дацитового и риодацитового состава, перекрытый озерными отложениями (см. таблицу, участок A1). Более уверенно можно интерпретировать высокоскоростную зону 2 (участок А3): область экструзивных куполов позднеплейстоценового возраста.

В нижней части разреза (профиль I) наблюдаются связанные между собой высокоскоростные области 3 и 4. Их можно интерпретировать как части верхнекорового магматического очага, по геологическим данным предполагаемого в недрах под депрессией с нижнечетвертичного времени и находящегося в стадии закристаллизации [Вулканизм..., 1974; Леонов, 1989; Леонов, Гриб, 1989; Леонов и др., 1991]. На рис. 4 он оконтурен белым штриховым пунктиром. Глубина залегания основной части очага (область 4) соответствует границе кристаллического фундамента и толщи слабопроницаемых вулканогенно-осадочных пород, проходящей под Узон-Гейзерной депрессией на глубине 6-7 км [Мороз, 1991]. Положение очага в конце средне-верхнечетвертичного времени фиксируется выходами системы дуговых даек на поверхность [Белоусов и др., 1983; Леонов, 1989]. По геолого-структурным данным в среднем плейстоцене размеры очага и его глубина залегания составляли 7-8 и 10 км соответственно (рис. 5в). Как видно, зоны 3 и 4 вписывается в рамки такой модели магматического очага (рис. 5б). Пространственное ограничение очага с севера и запада согласуется с расположением центров извержений кислых магм на посткальдерном этапе развития структуры [Вулканизм, 1974; Леонов, Гриб, 2004]. Наши результаты подтверждают предполо- 
Геологические характеристики участков профилей, выделенных на рис. 4

\begin{tabular}{|c|c|c|c|c|}
\hline Участок & & Структурная принадлежность & Подстилающие породы & Возраст \\
\hline \multirow[b]{2}{*}{ A1 } & \multicolumn{2}{|c|}{ C-3 край профиля I: Подходы к г. Белая } & Лавы дацитового и риодацитового состава & $Q_{3}^{3-4}$ \\
\hline & \multicolumn{2}{|c|}{ Центральная часть кальдеры Узон } & $\begin{array}{l}\text { Озерные отложения позднеплейстоценово- } \\
\text { го возраста (пачка второго озера и Южной } \\
\text { котловины) }\end{array}$ & $Q_{3}^{3-4}$ \\
\hline $\mathrm{A} 2$ & \multicolumn{2}{|c|}{ Восточная часть кальдеры Узон } & $\begin{array}{l}\text { Озерные отложения позднеплейстоценово- } \\
\text { го возраста (Пемзовая пачка) }\end{array}$ & $Q_{3}^{3-4}$ \\
\hline A3 & \multicolumn{2}{|r|}{$\begin{array}{l}\text { Перевал между кальдерой Узон и Долиной } \\
\text { гейзеров. Лавовый поток, связанный с экс- } \\
\text { трузивным куполом позднеплейстоценово- } \\
\text { го возраста }\end{array}$} & Лавы риолитового состава & $Q_{3}^{3-4}$ \\
\hline A4 & \multicolumn{2}{|c|}{$\begin{array}{l}\text { Правый борт р.Гейзерной. Центральная } \\
\text { часть Долины Гейзеров Позднеплейстоце- } \\
\text { новая экструзия дайкового комплекса }\end{array}$} & Лавы дацитового, риодацитового состава & $Q_{3}^{3-4}$ \\
\hline A5 & \multicolumn{2}{|c|}{$\begin{array}{l}\text { Центральная часть Гейзерного термального } \\
\text { поля. Левобережье р. Гейзерной }\end{array}$} & $\begin{array}{l}\text { Озерные отложения позднеплейстоценово- } \\
\text { го возраста (пачка гейзерная), мощность } \\
\text { около } 100 \text { м }\end{array}$ & $Q_{3}^{3-4}$ \\
\hline A6 & \multicolumn{2}{|c|}{$\begin{array}{l}\text { Склон восточного борта Узон-Гейзерной де- } \\
\text { прессии }\end{array}$} & $\begin{array}{l}\text { Озерные отложения позднеплейстоценово- } \\
\text { го возраста (пачка гейзерная) }\end{array}$ & $Q_{3}^{3-4}$ \\
\hline A7 & \multicolumn{2}{|c|}{$\begin{array}{l}\text { Восточный борт Узон-Гейзерной депрессии. } \\
\text { Позднеплейстоценовая экструзия бортово- } \\
\text { го комплекса }\end{array}$} & $\begin{array}{l}\text { Лавы преимущественно дацитового, риода- } \\
\text { цитового состава. }\end{array}$ & $Q_{3}^{3}$ \\
\hline A8 & \multicolumn{2}{|c|}{ Горное плато } & $\begin{array}{l}\text { Комплекс лав Горного плато: лавы андези- } \\
\text { тового, андезито-дацитового и дацитового } \\
\text { состава }\end{array}$ & $Q_{3}^{2}$ \\
\hline B1 & \multirow{4}{*}{ 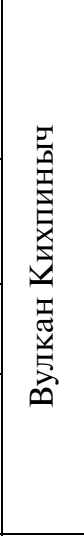 } & $\begin{array}{l}\text { Северо-западный и западный склон } \\
\text { вулканического массива Кихпиныч } \\
\text { (постройка вулкана Старый Кихпи- } \\
\text { ныч) }\end{array}$ & $\begin{array}{l}\text { Лавы и туфы базальтового, андезито-базаль- } \\
\text { тового и андезитового состава }\end{array}$ & $Q_{3}^{2-3}$ \\
\hline \multirow[t]{2}{*}{$\mathrm{B} 2$} & & $\begin{array}{l}\text { Верховье р. Гейзерной. Западный } \\
\text { склон вулканического массива Ких- } \\
\text { пиныч. }\end{array}$ & Озерные отложения (пачка Колорадо) & $Q_{3}^{4}-Q_{4}$ \\
\hline & & $\begin{array}{l}\text { Юг: Лавовый поток, связанный с экс- } \\
\text { трузивным куполом сопки Желтой }\end{array}$ & Лавы дацитового состава & $Q_{3}^{3-4}$ \\
\hline B3 & & $\begin{array}{l}\text { Западный склон вулканического мас- } \\
\text { сива Кихпиныч (сопки Желтой). Ла- } \\
\text { вовый поток, связанный с экструзив- } \\
\text { ным куполом сопки Желтой }\end{array}$ & Лавы риолитового состава & $Q_{3}^{3-4}$ \\
\hline B4 & \multicolumn{2}{|r|}{$\begin{array}{l}\text { Восточный борт Узон-Гейзерной депрессии. } \\
\text { Экструзия бортового комплекса }\end{array}$} & $\begin{array}{l}\text { Лавы преимущественно дацитового, риода- } \\
\text { цитового состава. }\end{array}$ & $Q_{3}^{3}$ \\
\hline B5 & \multicolumn{2}{|r|}{$\begin{array}{l}\text { Восточный борт Узон-Гейзерной депрессии } \\
\text { Горное плато }\end{array}$} & $\begin{array}{l}\text { Комплекс лав Горного плато: лавы андези- } \\
\text { тового, андезито-дацитового и дацитового } \\
\text { состава }\end{array}$ & $Q_{3}^{2}$ \\
\hline \multirow{2}{*}{ B6 } & \multicolumn{2}{|c|}{$\begin{array}{l}\text { Север: Восточный борт Узон-Гейзерной де- } \\
\text { прессии. Позднеплейстоценовая экструзия } \\
\text { бортового комплекса }\end{array}$} & $\begin{array}{l}\text { Лавы преимущественно дацитового, риода- } \\
\text { цитового состава }\end{array}$ & $Q_{3}^{3}$ \\
\hline & \multicolumn{2}{|c|}{ Горное плато } & $\begin{array}{l}\text { Комплекс лав Горного плато: лавы андези- } \\
\text { тового, андезито-дацитового и дацитового } \\
\text { состава }\end{array}$ & $Q_{3}^{2}$ \\
\hline B7 & \multicolumn{2}{|c|}{$\begin{array}{l}\text { Южный склон Кихпинычского долгоживу- } \\
\text { щего вулканического центра }\end{array}$} & $\begin{array}{l}\text { Нерасчлененные отложения докальдерного } \\
\text { комплекса (преимущественно лавы и туфы } \\
\text { андезитового и дацитового состава) }\end{array}$ & $Q_{2}$ \\
\hline
\end{tabular}


жение о том, что обширный кислый магматический очаг под депрессией к настоящему времени в значительной степени закристаллизовался и представляет собой интрузив сложной формы, проявляющийся на разрезе как относительно высокоскоростная область.

Субвертикальную относительно высокоскоростную структуру в диапазоне глубин 10-20 км под зоной 4, отмеченную на рис. 4 белым штриховым пунктиром со стрелкой, мы интерпретируем как часть древней магматической системы - область питающего канала, поднимающегося из глубин к закристаллизовавшемуся очагу под депрессией.

На разрезе (профиль $I$ ) также видно, что интрузивный комплекс имеет тенденцию к воздыманию под районом Долины Гейзеров. Его восходящая часть (область 3) пространственно связана с зоной прорыва на поверхность лав бортового комплекса (участок A7) на этапе формирования депрессии и полем позднеплейстоценовых экструзий - последних проявлений кислого вулканизма в пределах депрессии (участки А3-A4). Возможно, она явилась зоной питания этих вулканических аппаратов. Расположение области 3 непосредственно под Долиной Гейзеров (под участками А4-А6) позволяет предположить, что именно этот периферический очаг связан с процессом формирования в восточной части Узон-Гейзерной вулкано-тектонической депрессии Гейзерной кальдеры - наиболее древней части депрессии.

Относительно низкоскоростную зону 5, проявляюшуюся на всех разрезах I, II, IIa, на наш взгляд, следует рассматривать как зону нерасчлененных отложений докальдерного комплекса (вулканогенноосадочный чехол) в соответствии со свойствами выходящего на поверхность участка В7, который преимущественно представлен лавами базальтового, андезитового, дацитового, риодацитового состава.

На разрезах $\boldsymbol{I I}, \boldsymbol{I I - \boldsymbol { a }}$ отчетливо видна наклонная относительно высокоскоростная область 6, выходящая на дневную поверхность в зоне известных субширотных разрывных нарушений. Их простирание соответствует Узон-Валагинскому глубинному региональному разлому. Эта система нарушений прослеживается на поверхности как в пределах депрессии, так и на вулкане Кихпиныч серией сбросов с опущенным южным крылом, где амплитуда вертикальных смещений достигает 50-70 м, а длина - 3-4 км [Леонов, 1989]. Вероятно, субширотные сбросы играли существенную структурообразующую роль: именно они в основном сформировали уступ северного ограничения Узон-Гейзерной депрессии, и именно по системе субширотных сбросов произошло внедрение магмы в период последней вулканической активизации в восточной части депрессии. Можно предполагать, что зона 6 отражает пути распространения магмы по системе субширотных разрывных нару- шений, контролируемых региональным Узон-Валагинским разломом, в четвертичное время проявившим себя как структура растяжения.

В отличие от зоны 5, относительно низкоскоростную зону 7 (разрезы $\boldsymbol{I I}, \boldsymbol{I I a}$ ) в диапазоне глубин 5-10 км, видимо, следует интерпретировать как область повышенной концентрации базальтовой магмы, которая является периферическим очагом, питавшим голоценовые базальтоидные извержения Кихпинычского ДВЦ [Белоусов, 1978; Леонов, 2001]. В пользу этого предположения говорит ярко выраженная бимодальность проявления вулканизма (кислого и основного) на посткальдерном этапе развития Узон-Гейзерного кальдерного комплекса с одновременным развитием разобщенных в пространстве риодацитов и базальтоидов (рис. 2б). На рис. 4 область магматического очага под Кихпинычем оконтурена белым точечным штрихпунктиром. Глубина формирования очага 7 (как и интрузива 4) соответствует границе кристаллического фундамента и вулканогенно-осадочного покрова. Согласно [Леонов, Гриб, 2004] именно близость базальтового очага наряду с кислым интрузивом, а также эпизодические инъекции базальтов обеспечивают длительное существование Гейзерной гидротермальной системы и ее тепловое питание. Профили II и $\boldsymbol{I \boldsymbol { a }}$ не пересекают область молодых конусов вулкана Кихпиныч, поэтому их приповерхностные подводящие каналы они не проявляются на представленных разрезах. Однако под зоной 7 на глубине 10-25 км прослеживается изогнутая субвертикальная относительно низкоскоростная неоднородность (белый точечный штрихпунктир на рис. 4), которая может быть связана с поступлением глубинных базальтовых расплавов в периферический магматический очаг 7 под вулканом Кихпиныч.

На месте крупной относительно низкоскоростной зоны 8 на нижнем разрезе $\boldsymbol{I}$, в диапазоне глубин 15-20 км непосредственно под интрузивом 4, можно предположить наличие магматической камеры, формирование которой связано с частичным блокированием свободного распространения магмы к поверхности из-за экранирующей роли закристаллизовавшегося кислого очага 4.

Таким образом, интерпретируя результаты ММЗ в сопоставлении с имеющимися геологическими представлениями, мы отмечаем основные элементы магматической питающей системы Кихпинычского ДВЦ:

- древний малоглубинный закристаллизовавшийся магматический очаг (интрузив) неправильной формы в диапазоне глубин от 2-3 до 10-12 км под восточной частью Узон-Гейзерной депрессии (структуры 3 и 4, очерченные белым штриховым пунктиром на рис. 4);

- магматическая камера (область концентрации базальтовых расплавов) в диапазоне глубин 
15-20 км под древним закристаллизовавшимся очагом (структура 8 на рис. 4);

- современный периферический магматический очаг (область концентрации базальтовых расплавов) под вулканом Кихпиныч в диапазоне глубин 5-10 км (структура 7, очерченная белым точечным штрихпунктиром на рис. 4);

- возможные пути поступления магмы в магматические очаги, тяготеющие к верхней границе кристаллического фундамента, из более глубоких горизонтов (субвертикальные неоднородности на рис. 4 , которые отмечены белыми пунктирами со стрелками).

\section{СОПОСТАВЛЕНИЕ ПОЛУЧЕННЫХ РЕЗУЛЬТАТОВ С ДАННЫМИ СПУТНИКОВОЙ ИНТЕРФЕРОМЕТРИИ И ЛОКАЛЬНОЙ СЕЙСМИЧНОСТЬЮ}

Как уже упоминалось, в период 2000-2003 гг. в районе восточного борта Узон-Гейзерной депрессии было отмечено асейсмичное поднятие земной поверхности. При этом в 1999 г. и 2004 г. смещений выявлено не было, что позволяет рассматривать зафиксированное явление как эпизод локальной эндогенной активизации.

В соответствии с работой [Lundgren, Lu, 2006] наилучшую согласованность с зарегистрированной поверхностной деформацией показала модель наклонного магматического силла неправильной формы на глубине 4-8 км, заглубляющегося на северо-запад. Решение было получено с использованием модельного набора взаимосвязанных трещин с максимальным раскрытием около 0.5 м при избыточном давлении 1.6 МПа. Геометрия модели представлена на рис. 5а. Плоскость модельного силла соответствует верхней кромке магматического очага, модель которого была разработана по геологоструктурным данным в [Белоусов и др., 1983] и проиллюстрирована на рис. 5в.

Дополнительными аргументами, свидетельствующими об активизации геодинамических процессов исследуемого района, являются следующие факты:

- было обнаружено несколько новых крупных горячих и кипящих источников в апикальной части указанной зоны деформации, что свидетельствует о повышении пьезометрической поверхности и давления в Гейзерной гидротермальной системе [Кирюхин, 2011], где авторы рассматривают обвально-оползневые процессы в Долине Гейзеров как результат этих изменений в гидротермальном резервуаре, влияющих на снижение склоновой устойчивости.

- по материалам аэротепловой и наземной инфракрасной съемки 2010 г. были выявлены аномалии в наиболее молодой части Кихпинычского вулканического центра (конус Савича, Молодой
Кихпиныч): повышение температуры в верхней части конуса, появление новых прогретых площадок в прикратерной зоне конуса, появление белых возгонов, ранее не отмечавшихся [Карданова, Дубровская, 2012].

Зарегистрированная временно́й сетью сейсмичность также свидетельствует об активности в недрах Кихпинычского вулканического центра. Два выделенных пространственно разобщенных облака сейсмических событий соответствуют областям максимальных модельных глубинных подвижек, вызвавших поверхностную деформацию и ассоциируемых с внедряющейся магмой.

В этой ситуации особый интерес представляет сопоставление модели глубинного строения исследуемого района по ММЗ с модельными представлениями о внедряющемся магматическом силле, разработанными по результатам InSAR в [Lundgren, $\mathrm{Lu}, 2006]$.

Из рис. 5а видно, что максимальные модельные глубинные подвижки сконцентрированы в двух областях: (1) - под центральной частью поля экструзий в восточной части депрессии (участок A3-A4), что соответствует области последнего центра извержения кислых лав (возраст прорыва 15-20 тыс. лет); и (2) - под западным склоном вулканического массива Кихпиныч. Как видно из рис. 2 и рис. 5а, профиль $I$ проходит над первой из указанных областей. На рис. рис. 5б показаны величины модельных смешений в плоскости внедряюшегося силла под профилем $\boldsymbol{I}$. Учитывая глубину и геометрию модели, мы видим, что участок максимальных смещений пространственно соответствует нижней части относительно низкоскоростной зоны 5* (профиль $I$ ). В настоящее время нет каких-либо экспериментальных данных, указывающих на существование в зоне $5 *$ обширной близповерхностной области, насыщенной магматическим расплавом. Поэтому мы склонны считать, что имеет место внедрение магматического тела в нижней части зоны $5 *$ с возможным его продвижением к поверхности по наклонной границе между телом 5* и интрузивами 3 и 4 (черная пунктирная линия со стрелками на рис. 4 и рис. 5б). Зона контакта этих интрузий с вмещающей вулканогенно-осадочной толщей $5 *$ представляется наиболее предпочтительным путем распространения магматического расплава в неоднородной среде. Областью магматического питания развивающегося силла может быть низкоскоростная зона 7 или другие более глубокие источники (например, зона 8), магма из которых поднимается по периферии закристаллизовавшегося кислого очага 4.

Что касается локальной сейсмичности, то землетрясения (гp. I) ложатся на границу между областями 5* и 3, "маркируя" их зону контакта. Напрашивается предположение, что эта сейсмичность инициирована поднятием магмы по границе между 
вулканогенно-осадочной толщей и закристаллизовавшимся магматическим очагом. Рис. 56 иллюстрирует предполагаемое положение внедрения магматического силла на разрезе вдоль профиля $\boldsymbol{I}$ микросейсмической съемки, на который спроецированы гипоцентры облака локальных землетрясений, выделенных на рис. 3 как гр. $\boldsymbol{\Gamma}$.

Таким образом, по комплексу независимых геолого-геофизических данных можно говорить о геодинамической активизации Кихпинычского ДВЦ, связанного со скрытым продвижением магмы к поверхности. При этом проведенные по методу ММЗ исследования в сопоставлении с данными по сейсмичности и моделью глубинного источника поверхностной деформации позволяют уточнить предполагаемое положение магматического внедрения. Мы предполагаем, что магматическое внедрение может происходить наклонно по периферии закристаллизовавшегося магматического очага в диапазоне глубин 4-6 км под восточной частью Узон-Гейзерной депрессии. По всей видимости, магма поступает из обнаруженных низкоскоростных структур: периферического очага вулкана Кихпиныч (рис. 4, структура 7) или более глубокой магматической камеры (рис. 4, структура 8).

\section{ЗАКЛЮЧЕНИЕ}

В восточной части Узон-Гейзерной вулкано-тектонической депрессии, где по данным независимых геолого-геофизических исследований ( $S A R$-интерферометрия, термогидродинамические наблюдения, тепловая и инфракрасная съемка, временны́е сейсмологические наблюдения, процессы склоновой неустойчивости) в 2000-2014 гг. наблюдается локальная геодинамическая активизация, в соответствии с технологией ММЗ выполнена профильная микросейсмическая съемка - регистрация естественного фонового микросейсмического поля широкополосными сейсмометрами Guralp CMG-6TD. Профили наблюдений были спланированы с учетом сложного рельефа, с учетом имеющихся данных о геологическом строении района и результатов $S A R$-интерферометрии. Измерения были проведены в 60 точках вдоль трех профилей общей длиной около 28 км. Съемкой был охвачен район над глубинным магматическим внедрением, вызвавшим в 2000-2014 гг. ряд поверхностных явлений: 1) деформацию земной поверхности; 2) изменение термодинамических параметров гидротермальной системы, появление новых горячих и кипящих источников; 3) разогрев наиболее молодого конуса вулканического массива Кихпиныч и 4) предположительно, катастрофические обвально-оползневые явления в Долине Гейзеров.

Вдоль профилей построены глубинные разрезы до 30 км, отражающие распределение относительных скоростей поперечных сейсмических волн. Выполнена их комплексная интерпретация с ис- пользованием известных ранее результатов геологических, геолого-морфологических и петрологических исследований. Обнаружено, что полученные разрезы хорошо согласуются в своей верхней части с геологическими особенностями строения исследуемого района.

На основании инструментальных сейсмологических наблюдений впервые удалось проанализировать особенности строения магматической системы долгоживущего вулканического центра. Были локализованы разновозрастные магматические камеры, обусловившие миграцию центров извержений, а также питающие обособленные глубинные магматические каналы.

Идентифицирована и пространственно определена область древнего магматического очага кислого состава под Узон-Гейзерной депрессией. Полученные результаты подтверждают предположение о том, что обширный магматический очаг под депрессией к настоящему времени в значительной степени закристаллизовался и представляет собой интрузив сложной формы, проявляющийся на разрезе как относительно высокоскоростная область на глубинах $2-12 \mathrm{KM}$.

Выявлены и локализованы предположительные области концентрации базальтовых расплавов: магматическая камера в диапазоне глубин 1520 км под древним закристаллизовавшимся очагом и современный периферический магматический очаг непосредственно под вулканическим массивом Кихпиныч в диапазоне глубин 5-12 км. Предполагается, что магма именно из этих областей продвигается по периферии древнего очага и питает развивающееся магматическое внедрение.

Получено согласие геометрии обнаруженных глубинных структур с локальной слабой сейсмичностью и моделью внедрения магмы в верхние горизонты коры по данным спутниковой интерферометрии, что позволяет уточнить возможное положение магматического внедрения.

Важным методическим результатом проведенных исследований является схожесть полученных результатов по профилям $\boldsymbol{I I}$ (северная часть) и $\boldsymbol{I I - \boldsymbol { a }}$, заложенным параллельно на расстоянии 500 м друг от друга. Эти участки съемки изначально были ориентированы на подтверждение достоверности полученных результатов в случае их взаимного соответствия. Проведенный натурный эксперимент оказался удачным и показал схожесть полученных разрезов, что подтверждает существование неоднородностей, выявленных по независимым профильным данным, и позволяют с доверием отнестись к остальным результатам представленного исследования глубинного строения.

Авторы выражают признательность В.Л. Леонову (Институт вулканологии и сейсмологии ДВО РАН) за консультации и ценные замечания в ходе подготовки публикации. 
Авторы также благодарят администрацию Кроноцкого заповедника за всестороннее содействие полевому отряду при проведении научных экспедиций на исследуемой территории.

Работа выполнена при частичной финансовой поддержке научных проектов РФФИ (грант 1005-00139, 13-05-00117).

\section{СПИСОК ЛИТЕРАТУРЫ}

Белоусов В.И. Геология геотермальных полей в областях современного вулканизма. М.: Наука. 1978. 174 с. Белоусов В.И., Гриб Е.Н., Леонов В.Л. Геологические позиции гидротермальных систем Долины Гейзеров и кальдеры Узон // Вулканология и сейсмология. 1983. № 1. С. $65-79$.

Брайцева О.А., Флоренский И.В., Волынеи О.Н. Вулкан Кихпиныч // Действующие вулканы Камчатки. Т. 2. М.: Наука. 1991. С. 74-93.

Брайцева О.А., Флоренский И.В., Пономарева В.В., Литасов C.H. История активности вулкана Кихпиныч в голоцене // Вулканология и сейсмология. 1985. № 6. С. 3-19.

Вулканизм, гидротермальный процесс и рудообразование. М.: Недра. 1974. 264 с.

Горбатиков А.В., Ларин Н.В., Моисеев Е.И., Беляшов А.В. Применение метода микросейсмического зондирования для изучения строения погребенной трубки взрыва // ДокЛ. РАН. 2009. Т. 428. № 4. С. 526-530.

Горбатиков А.В., Рогожин Е.А., Степанова М.Ю., Харазова Ю.В., Андреева Н.В., Передерин Ф.В., Заалишвили В.Б., Мельков Д.А., Дзеранов Б.В., Дзебоев Б.А., Габараев А.Ф. Особенности глубинного строения и современной тектоники Большого Кавказа в Осетинском секторе по комплексу геофизических данных // Физика Земли. 2015. № 1. С. 1-12.

Горбатиков А.В., Степанова М.Ю., Кораблев Г.Е. Закономерности формирования микросейсмического поля под влиянием локальных геологических неоднородностей и зондирование среды с помощью микросейсм // Физика Земли. 2008. № 7. С. 66-84.

Горбатиков А.В., Степанова М.Ю., Цуканов А.А., Тинакин О.В., Комаров А.Ю., Одиниов С.Л., Токман А.К. Новая технология микросейсмического зондирования для изучения глубинного строения месторождений нефти и газа // Нефтяное хозяйство. 2010. № 6. C. $15-17$.

Горбатиков А.В., Овсюченко А.Н., Рогожин Е.А., Степанова М.Ю., Ларин Н.В. Сейсмотектоника и глубинное строение зоны Владикавказского активного разлома // Геофизические исследования. 2011. 12(1). С. 47-59.

Горбатиков А.В., Цуканов А.А. Моделирование волн Рэлея вблизи рассеивающих скоростных неоднородностей. Изучение возможностей метода микросейсмического зондирования // Физика Земли. 2011. № 4. C. $96-112$.

Двигало В.Н., Мелекесиев И.В. Геолого-геоморфологичские последствия катастрофических обвальных и обвально-оползневых процессов в Камчатской Долине Гейзеров (по данным аэрофотограмметрии) // Вулканология и сейсмология. 2009. № 5. С. 24-37.
Карданова О.Ф., Дубровская И.К. Термоаномалии в кратере вулкана Старый Кихпиныч и на конусе Савича (результаты данных ИК-съемки и наземных наблюдений за 30 лет: 1980-2010 гг.). Мат. конф. "Вулканизм и связанные с ним процессы”. Петропавловск-Камчатский. ИВиС ДВО РАН. 2012. С. 42-49.

Кирюхин А.В., Рычкова Т.В. Условия формирования и состояние гидротермальной системы Долины Гейзеров (Кроноцкий заповедник, Камчатка) // Геоэкология. 2011. № 3. С. 238-253.

Королева Т.Ю., Яновская Т.Б., Патрушева С.С. Использование сейсмического шума для определения структуры верхней толщи Земли // Физика Земли. 2009. № 5. C. 3-14.

Кугаенко Ю.А., Салтыков В.А., Коновалова А.А. Локальная сейсмичность района Долины Гейзеров по данных полевых наблюдений 2008-2009 гг. // Вестн. КРАУНЦ. Науки о Земле. 2010. № 1. Вып. 15. С. 90-99.

Кугаенко Ю.А., Салтыков В.А., Горбатиков А.В., Степанова М.Ю. Особенности глубинного строения района Северного прорыва Большого трещинного Толбачинского извержения 1975-1976 гг. по данным микросейсмического зондирования // Вулканология и сейсмология. 2013. № 5. С. 23-39.

Леонов В.Л. Обвал и оползень, произошедшие 4 января 2014 г. в Долине Гейзеров, Камчатка, и их последствия // Вестн. КРАУНЦ. Науки о Земле. 2014. № 1. Вып. 23. C. 7-20.

Леонов В.Л. Разрывные нарушения Узон-Гейзерной депрессии // Вулканология и сейсмология. 1982. № 4. С. $78-83$.

Леонов В.Л. Региональные структурные позиции высокотемпературных гидротермальных систем на Камчатке // Вулканология и сейсмология. 2001. № 5. С. 32-47. Леонов В.Л. Структурные условия локализации высокотемпературных гидротерм. М.: Наука. 1989. 104 с.

Леонов В.Л., Гриб Е.К., Карпов Г.А., Сугробов В.М., Сугробова Н.Г., Зубин М.И. Кальдера Узон и Долина Гейзеров. Действующие вулканы Камчатки. Т. 2. М.: Наука. 1991. С.94-143.

Леонов В.Л., Гриб Е.Н. Кальдеры и игнимбриты УзонСемячинского района, Камчатка: новые данные по результатам изучения разреза плато Широкое // Вулканология и сейсмология. 1998. № 3. С. 41-59.

Леонов В.Л., Гриб Е.Н. Структурные позиции и вулканизм четвертичных кальдер Камчатки. Владивосток: Дальнаука. 2004. 189 с.

Мороз Ю.Ф. Строение осадочно-вулканогенного чехла Камчатки по геофизическим данным // Тихоокеанская геология. 1991. № 1. С. 59-67.

Мороз Ю.Ф., Карпов Г.А., Мороз Т.А., Николаева А.Г., Логинов В.A. Строение кальдеры Узон на Камчатке по геофизическим данным. Мат. конф. "Вулканизм и связанные с ним процессы”. Петропавловск-Камчатский. ИВиС ДВО РАН. 2013. С. 233-240.

Пинегина Т.К., Делемень И.Ф., Дрознин В.А., Калачева Е.Г., Чирков С.А., Двигало В.Н., Леонов В.Л., Мелекесиев И.В., Селиверстов Н.И. Камчатская Долина Гейзеров после катастрофы 3 июня 2007 г. // Вестн. ДВО РАН. 2008. № 1. С. 33-44.

Пономарева В.В., Брайцева О.Б. Вулканическая опасность для района Кроноцкое озеро-Узон-Долина 
Гейзеров // Вулканология и сейсмология. 1990. № 1. C. $27-44$.

Рогожин Е.А., Харазова Ю.В., Горбатиков А.В., Шанов С.А., Степанова М.Ю., Митев А.А. Строение и современная активность Интрамизийского разлома в Северо-Восточной Болгарии по комплексу новых геолого-геофизических методов // Физика Земли. 2009. № 9. С. 66-74.

Федотов С.А. Энергетическая классификация КурилоКамчатских землетрясений и проблема магнитуд. М.: Наука. 1972. 116 c.

Чебров В.Н., Кугаенко Ю.А., Викулина С.А. и др. Глубокое Охотоморское землетрясение 24.05.2013 с магнитудой $M_{W}=8.3-$ сильнейшее сейсмическое событие у берегов Камчатки за период детальных сейсмологических наблюдений // Вестн. КРАУНЦ. 2013. № 1. Вып. 21. C. 17-24.

Bindeman I.N., Leonov V.L., Izbekov P.E., Ponomareva V.V., Watts K.E., Shipley N.K., Perepelov A.B., Bazanova L.I., Jich, B.R., Singer B.S., Schmitt A.K., Portnyagin M.V., Chen C.H. Large-volume silicic volcanism in Kamchatka: Ar$\mathrm{Ar}, \mathrm{U}-\mathrm{Pb}$ ages, isotopic, and geochemical characteristics of major pre-Holocene caldera-forming eruptions // J. Volcanol. Geotherm. Res. 2010. V. 189. № 1-2. P. 57-80.

Chavez-Garcia F.J., Rodriguez M., Stephenson W.R. An alternative approach to the SPAC analysis of microtremors: exploiting stationarity of noise // Bull. Seism. Soc. Am. 2005. V. 95. № 1. P. 277-293.

Dzurisin D., Lisowski M., Wicks Ch.W. Continuing inflation at Three Sisters volcanic center, central Oregon Cascade Range, USA, from GPS, leveling, and InSAR observations // Bull. of Volcanology. V. 71. № 10. P. 10911110 .

Gerstoft P., Sabra K.G., Roux P., Kuperman W.A., Fehler M.C. Green's functions extraction and surface-wave tomography from microseisms in southern California // Geophysics. 2006. V. 71. № 4. P. 23-31.

Gorbatikov A.V., Montesinos F.G., Arnoso J., Stepanova M.Yu., Benavent M., Tsukanov A.A. New features in the subsurface structure model of El Hierro Island $(\mathrm{Ca}-$ naries) from low-frequency microseismic sounding. An insight into the 2011 seismo-volcanic crisis // J. Surveys in Geophysics. 2013. V. 34. Is. 4. P. 463-489. DOI $10.1007 / \mathrm{s} 10712-013-9240-4$.
Lin F., Moschetti M.P., Ritzwoller M.H. Surface wave tomography of the western United States from ambient seismic noise: Rayleigh and Love wave phase velocity maps // Geophys. J. Int. 2008. Doi: 10.1111/j.1365246X.2008.03720.

Lu Z., Wicks C., Dzurisin D., Thatcher W., Freymueller J., McNutt S. and Mann D. Aseismic Inflation of Westdahl Volcano, Alaska, Revealed by Satellite Radar Interferometry // Geophys. Res. Lett. 2000. V. 27. Is. 11. P. 1567-1570. DOI: 10.1029/1999GL011283.

Lu Z., Wicks Jr. C., Dzurisin D., Power J.A., Moran S.C., and Thatcher $W$. Magmatic inflation at a dormant stratovolcano: 1996-1998 activity at Mount Peulik volcano, Alas$\mathrm{ka}$, revealed by satellite radar interferometry // Journal of Geophysical Research. V. 107. Is. 11. Doi: 10.1029/2001JB000471.

Lundgren P., Lu Zh. Inflation model of Uzon caldera, Kamchatka, constrained by satellite radar interferometry observations // Geophysical Research Letters. 2006. V. 33. L06301. Doi: 10.1029/2005GL025181.

Pritchard M.E., Simons M. Surveying Volcanic Arcs with Satellite Radar Interferometry: The Central Andes, Kamchatka, and Beyond // GSA Today. 2004. V. 14. № 8. P. 4-11.

Sabra K.G., Gerstoft P., Roux P., Kuperman W.A., Fehler M.C. Extracting time-domain Greens function estimates from ambient seismic noise // Geophys. Res. Lett. 2005. V. 32. L03310. Doi: 10.1029/2004GL021862.

Shapiro N.M., Campillo M. Emergence of broadband Rayleigh waves from correlations of the ambient seismic noise // Geophys. Res. Lett. 2004. V. 31. L07614. Doi: 10.1029/2004GL019491.

Shapiro N.M., Campillo M., Stehly L., Ritzwoller M.H. Highresolution surface-wave tomography from ambient seismic noise // Science. 2005. V. 307. P. 1615-1618.

Stehly L., Fry B., Campillo M. et al. Tomography of the Alpine region from observations of seismic ambient noise // Geophys. J. Int. 2009. V. 178. Doi: 10.1111/j.1365246X.2009.04132.x.

Yang Y., Ritzwoller M.H. Characteristics of ambient seismic noise as a source for surface wave tomography // Geochem. Geophys. Geosyst. 2008. V. 9. Q02008. Doi: 10.1029/2007GC001814. 


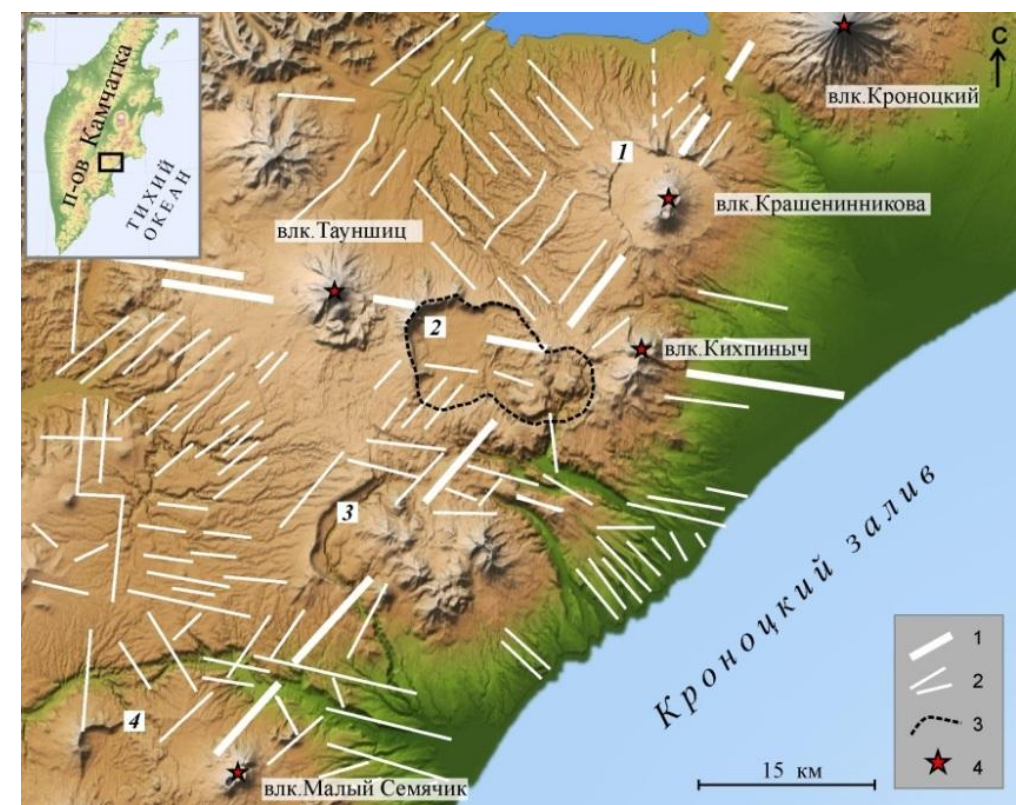

(a)
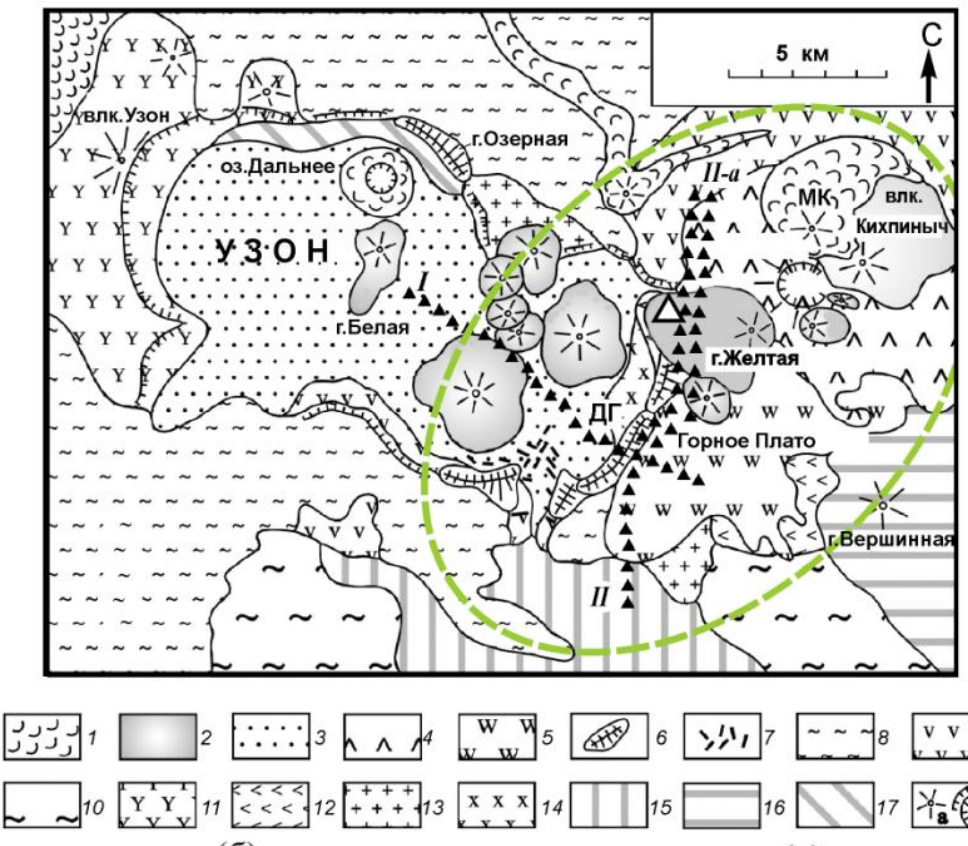

(б)
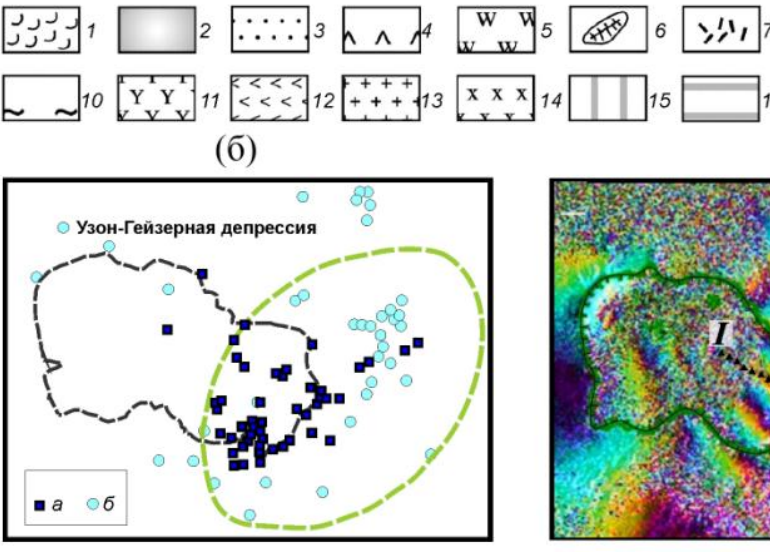

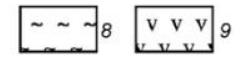

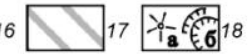

(B)

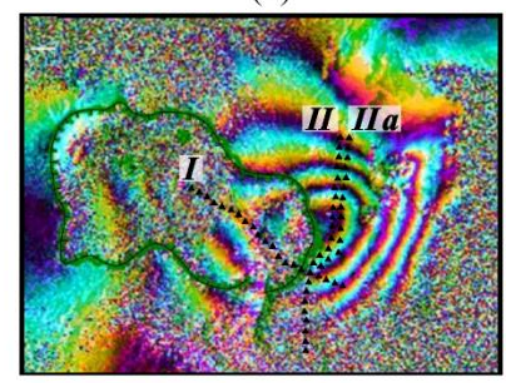

Рис.1 Схема вулканических объектов и разрывных нарушений центральной части Восточно-Камчатского вулканического пояса. Цифрами на карте обозначены кальдеры и вулкано-тектонические депрессии: 1 Крашенинникова, 2 - Узон-Гейзерная; 3 Большой Семячик, 4 - Стена-Соболиный. В легенде: 1 - осевые линии зон региональных разломов северо-восточного простирания (Вулканического раздвига) и субширотного простирания (Узон-Валагинского глубинного сдвига), пересекающих Узон-Гейзерный район; 2 - разрывные нарушения; 3 - граница УзонГейзерной вулкано-тектонической депрессии. Разрывные нарушения нанесены по [Леонов, 1982].
Рис.2. Район проведения микросейсмического зондирования: Узон-Гейзерная вулканотектоническая депрессия и вулканический массив Кихпиныч:

(a) - схематическая геологическая карта (по [Леонов, Гриб, 2004]).

На карту-схему нанесены реперы профилей микросейсмической съемки (черные треугольники) и опорная станция (белый треугольник). Условные обозначения: Голоцен: 1 - лавы андезитового, андезибазальтового состава. Верхний плейстоцен: 2 - лавы дацитового, риодацитового состава; 3 - озерные отложения, заполняющие Узон-Гейзерную депрессию; 4 - лавы базальтового состава (вулкан Кихпиныч); 5 - лавы андезитового состава; 6 - комплекс бортовых экструзий; 7 дайковый комплекс; 8 - игнимбриты, связанные с формированием Узон-Гейзерной депрессии; 9 - лавы андезитового состава («андезиты бортов»). Средний плейстоцен: 10 - игнимбриты, связанные с формированием Большесемячикской кальдеры; 11 - лавы базальтового, андезибазальтового состава (вулкан Узон); 12 - лавы базальтового состава (Горное Плато); 13 - лавы риодацитового состава; 14 - лавы дацитового состава; 15 лавы андезитового, андезибазальтового состава. Нижний - средний плейстоцен: 16,17 - лавы базальтового состава; 18 - центры вулканических построек (а); границы УзонГейзерной депрессии, кратера вулкана Старый Кихпиныч, маара оз. Дальнего (б). ДГ Долина Гейзеров, МК - Молодой Кихпиныч. Эллипсом оконтурен Кихпинычский долгоживущий вулканический центр; (б) схема расположения центров извержений в районе Узон-Гейзерной вулкано-тектонической депрессии и вулканического массива Кихпиныч (по [ Леонов, 2011; Леонов, Гриб, 2004; Леонов и др., 1991]). Центры извержений: $a$ - кислые породы: риолиты, риодациты, дациты; $\sigma$ - основные породы: андезиты. Эллипсом отмечен Кихпинычский долгоживущий вулканический центр; (в) - интерферограмма на район Узон-Гейзерной депрессии по [Lundgren, Lu, 2006], рассчитанная по паре снимков RADARSAT-1 за 19.09.2000 и 11.08.2003. Границы Узон-Гейзерной депрессии показаны линией с бергштрихами. Концентрические фигуры, приуроченные к восточной части депрессии - район поднятия. Цикл окраски соответствует смещению поверхности на 2.8 см в зоне прямой видимости спутника. На интерферограмму нанесены профили микросейсмической съемки. 
(a)

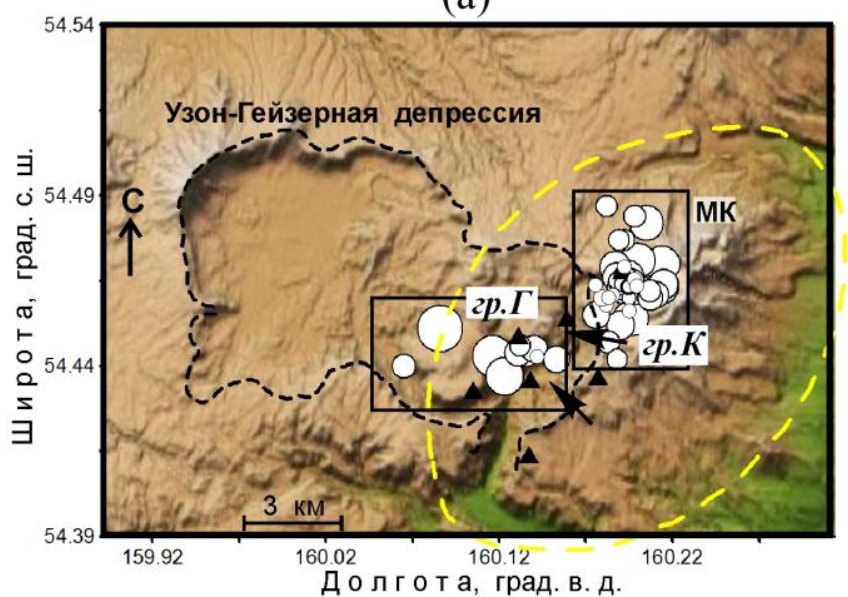

(б)

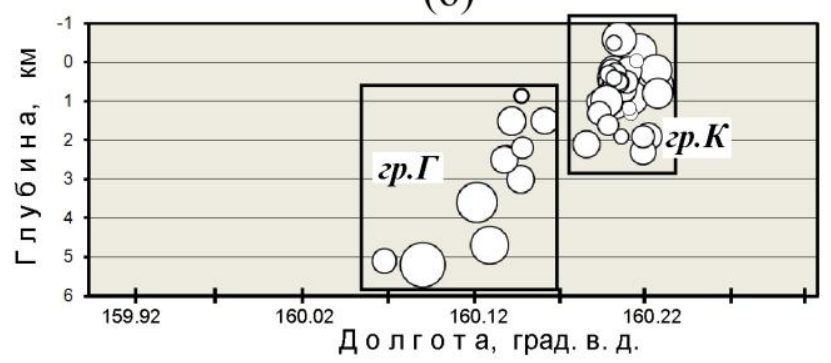

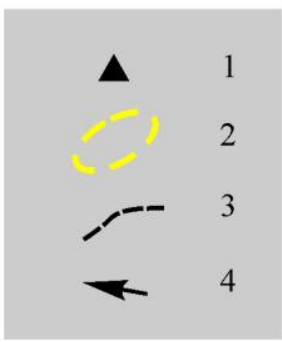

Эпицентры землетрясений

Энергетический $\begin{array}{llll}\text { класс } & \circ & 0 & \bigcirc \\ \text { Кs } & 4 & 5 & 6\end{array}$
Рис.3 Локальная сейсмичность по данным полевых наблюдений 20082009 гг.: (а) - карта эпицентров; (б) - вертикальный широтный разрез. Эпицентры локальных землетрясений энергетического класса Ks=4-7 обозначены кружками. В легенде: 1 - временные сейсмические станции; 2 - граница Кихпинычского долгоживущего вулканического центра; 3 - граница Узон-Гейзерной вулканотектонической депрессии; 4 районы формирования обвальнооползневых процессов 2007 г. и 2014 г. в Долине Гейзеров. Эллипсом оконтурен Кихпинычский долгоживущий вулканический центр, МК - вулкан Молодой Кихпиныч. Выделенные прямоугольниками группы землетрясений гр. $\boldsymbol{\Gamma}$ и гр. $\boldsymbol{K}$ описаны в тексте. (a)

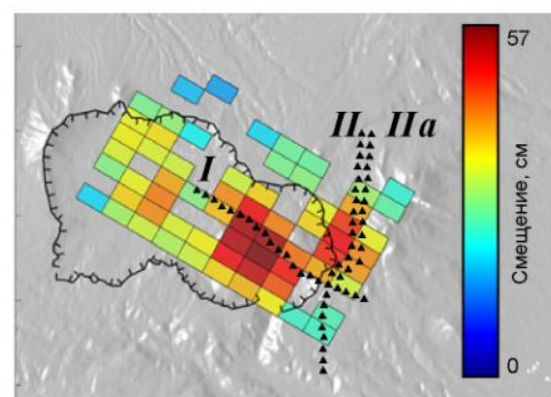

Относительная интенсивность, дБ

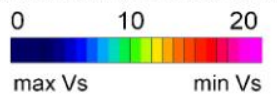

(б)

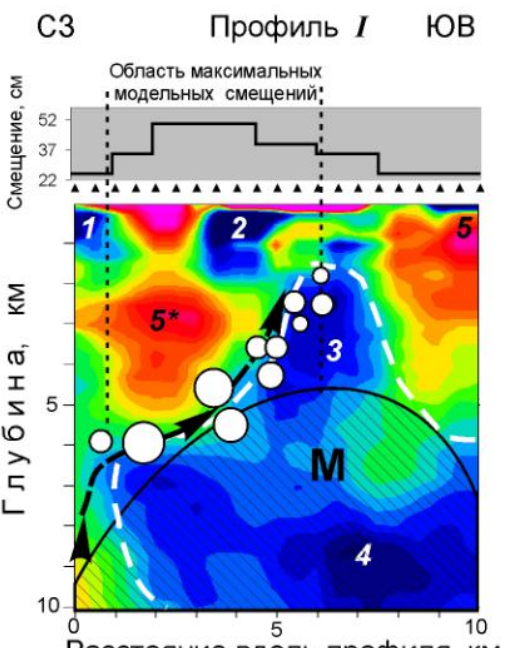

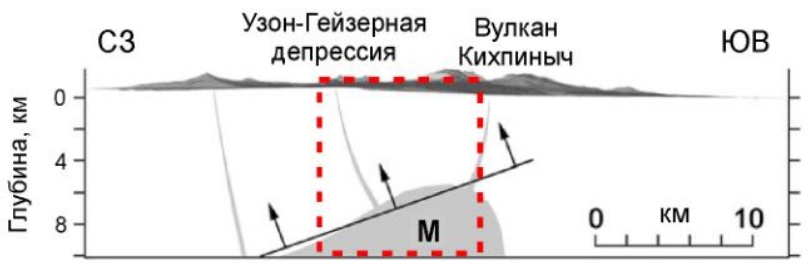

Рис. 5 Сопоставление результатов микросейсмического зондирования с данными спутниковой интерферометрии и локальной сейсмичностью:

(a) - модель глубинного источника поверхностной деформации по [Lundgren, Lu, 2006] - неоднородный набор взаимосвязанных источников трещинного типа с различным раскрытием под действием избыточного давления. На схему нанесены профили микросейсмической съемки. Границы Узон-Гейзерной депрессии показаны линией с бергштрихами;

(б) - фрагмент разреза вдоль профиля $\boldsymbol{I}$ до глубины 10 км. Нумерация элементов глубинной структуры соответствует рис. 4. На разрез нанесены проекции гипоцентров локальных землетрясений с $\mathrm{K}_{\mathrm{S}}=4-7$ по [Кугаенко и др., 2010] (кружки) и контуры магматического очага (М) по [Белоусов и др., 1983]. В верхней части рисунка представлен график, показывающий величины модельных смещений под профилем $\boldsymbol{I}$ в соответствии с моделью глубинного источника поверхностной деформации (рис.5a) по [Lundgren, Lu, 2006]. Пунктирные линии на разрезе соответствуют рис. 4: белый пунктир - условная граница закристаллизовавшегося магматического очага под Узон-Гейзерной депрессией; черный пунктир - предполагаемое положение магматического силла, внедряющегося из более глубоких горизонтов по границе закристаллизовавшегося магматического очага и вулканогенно-осадочной толщи 5 *; (в) - вид сбоку на модель источника деформации, приведенную на рис.5а по [Lundgren, Lu, 2006] и магматический очаг (М) по [Белоусов и др., 1983]. Квадратом выделена область, соответствующая фрагменту разреза I, который представлен на рис.5б. 

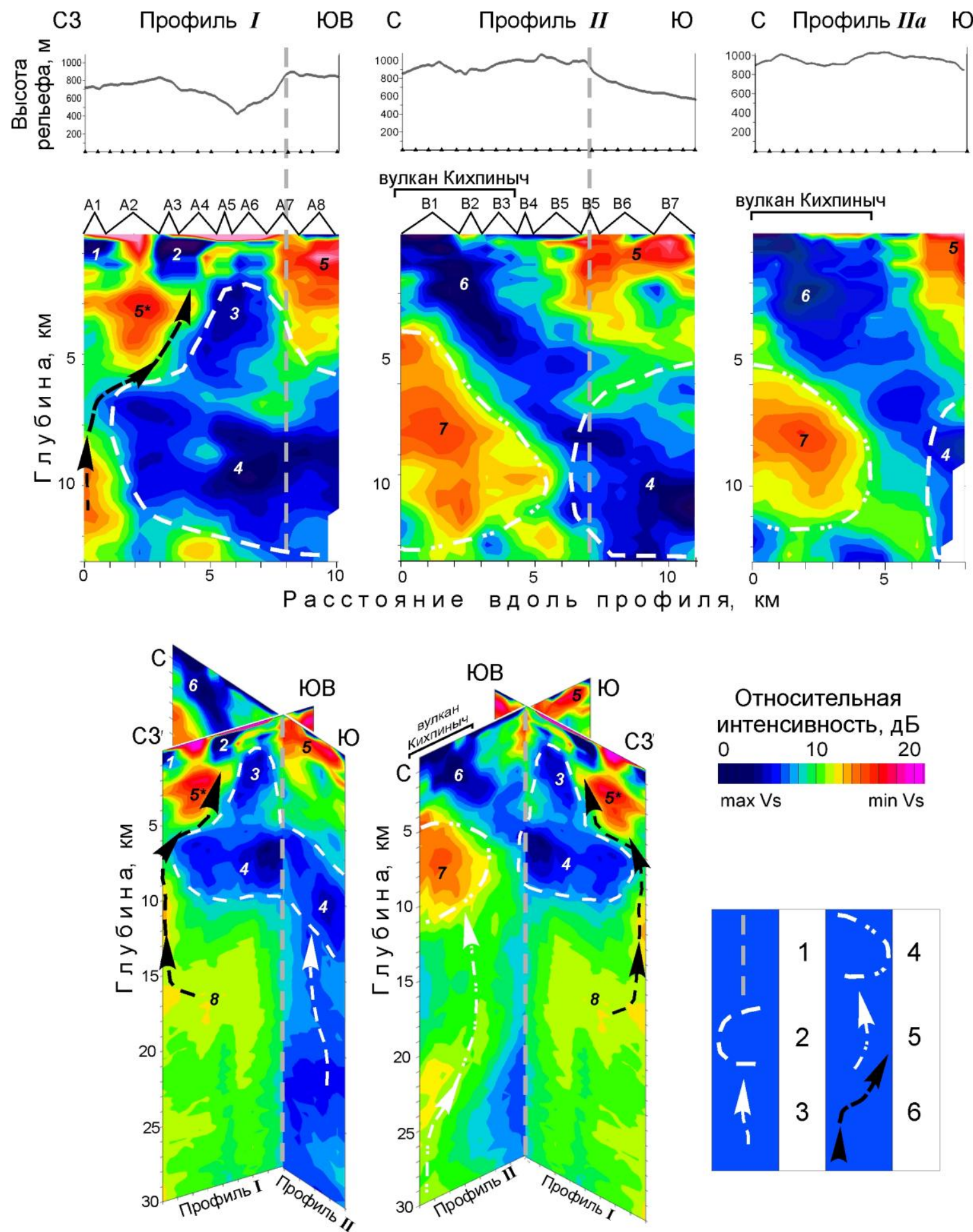

Рис. 4 Глубинные разрезы вдоль микросейсмических профилей в параметрах относительных скоростей поперечных сейсмических волн (с элементами интерпретации). Вверху: до глубины 12 км. Внизу: квази-3D представление до глубины 30 км. Поверхностные участки с различным геологическим строением пронумерованы в соответствии с таблицей. На разрезах цифрами обозначены выявленные глубинные неоднородности, более подробно описанные в тексте: 1 - область экструзивного купола г. Белой, частично перекрытого озерными отложениями; 2 - поле развития экструзивных куполов в восточной части депрессии; 3,4 - связанные между собой части верхнекорового закристаллизовавшегося магматического очага под Узон-Гейзерной депрессией; 5,5 * блоки нерасчлененных отложений докальдерного комплекса (вулканогенноосадочный чехол); 6 - пути распространения магмы по системе субширотных разрывных нарушений, контролируемых региональным Узон-Валагинским разломом; 7 - периферический очаг, питающий голоценовые базальтоидные извержения Кихпинычского вулканического центра; 8 - область скопления базальтовых расплавов, образованная ввиду экранирующей роли кислого интрузива 4 , расположенного выше.

Пунктирные линии в легенде: 1 - линия пересечения разрезов $\boldsymbol{I}$ и $\boldsymbol{I I} ; 2$ - условная граница закристаллизовавшегося магматического очага под Узон-Гейзерной депрессией; 3 -«корень», питавший очаг под Узон-Гейзерной депрессией; 4 условная граница периферического магматического очага вулкана Кихпиныч; 5 - «корень», питавший очаг вулкана Кихпиныч; 6 - предполагаемое положение магматического силла, внедряющегося из более глубоких горизонтов по границе магматических интрузий 3 и 4 (закристаллизовавшегося магматического очага) и вулканогенно-осадочной толщи $5 *$. 